Portland State University

PDXScholar

1976

\title{
Leadership Styles and Staff Satisfaction in Four Nursing Homes: Implications for Service Delivery
}

Carol Nightengale

Portland State University

Follow this and additional works at: https://pdxscholar.library.pdx.edu/open_access_etds

Part of the Social Work Commons

Let us know how access to this document benefits you.

\section{Recommended Citation}

Nightengale, Carol, "Leadership Styles and Staff Satisfaction in Four Nursing Homes: Implications for Service Delivery" (1976). Dissertations and Theses. Paper 1907.

https://doi.org/10.15760/etd.1906

This Thesis is brought to you for free and open access. It has been accepted for inclusion in Dissertations and Theses by an authorized administrator of PDXScholar. Please contact us if we can make this document more accessible: pdxscholar@pdx.edu. 


\section{LEADERSHIP STYLES AND STAFF SATISFACTION \\ IN FCUR NURSING HOMES: \\ TMPLICATIONS FOR SERVICE DELIVERY}

by

CAROL NIGHTENGALE
A report submitted in partial fulfillment of the requirements for the degree of
MASTER OF
SOCIAL WORK

Portland State University

1976 
ACKNOWIEDGMENTS

In recent years the nursing home industry has changed from selfregulation to federal regulation. One of the results of the federal regulations is that many people involved in the nursing home industry feel overly observed and defensive. Recognizing this prevailing attitude of the time, I sincerely thank the nursing home administrators for their willingness to frankly share their feelings concerning this study, the nursing home industry, and the role of the social work consultant in nursing homes. Their frank comments greatly enhanced this study. Special thanks are extended to the staff and administrators of the four nursing homes who felt able to transcend their difficult situation and participate in this study.

Appreciation is also extended to Lowis Curtis, who assumed the task of practicum advisor; to Frank Miles, who assisted with the development of the questionaire; to Ellen Sensat, who assisted with computer programming; and to family, who assisted with the proof reading and typing. Their willingness to assist with this study and their availability are greatly appreciated. 
Page

1. Chapter 1: The Problom ........ 1

A. The Aims and Rationale for the Study. - I

B. Assumptions ............ 1

C. Review of the Literature...... 5

D. Questions to be Explored...... 10

11. Chapter 11: Methodology. . . . . 12

A. The Selection of Nursing Homes. . . 12

B. Description of Homes....... 13

C. The Samplo.......... 15

D. The Schedule......... 17

E. The Proceedure....... 18

F. The Responses . . . . . 19

111. Chapter 111: Results . . . . . . 21

A. Analysis and Findings ....... 21

B. Limitations ........ 31

C. Suggestions for Further Research. - - 32

D. Implications ...... 36

IV. Bibliography .......... 38

V. Appendices ..................... 40

A. Biographical Responses and Percentages. 41

B. Cover Sheet for Schedulo ..... 42

C. Interview Schedulo ....... 43

D. Responses and Percentages ..... 46

E. Significant Relationships with Non-democratic Leadersin Styles ...... 50 
CHAPTER I

THE PRCBLEM

A. THE AINS AND RATIONALE FOR THE STUDY

This is a study of four nursing care facilities in Fortland, Cregon in 1975-1976, which examines the relationship between leadership style and staff satisfaction, leadership style and patient satisfaction, and staff satisfaction and patient satisfaction.

Experientially administrative style seems to have an impact on staff and cllents. If this is the case, administrators, supervisors, and direct service people need to be aware of this impact on service delivery systems and individual clients to selectively support the most beneficial leadership style.

This study examines nursing home settings because they are primary service delivery systems, they employ a variety of professionals and nonprofessionals, and they are a secondary setting for social workers. Further motivation for choosing mursing home settings includes the lack of research involving nursing care facilities, especially pertaining to social work consultation.

\section{B. ASSUMPTICNS}

Organizational theory provides a way of examining leadership styles in nursing home settings. "An organizational theory is a conceptual point of reference that prepares us to better understand an organization. It is not limited to the tight logical meaning it carries in the hard sciences but rather takes on a more generalized and flexible mean- 
determines policy and makes all decisions." 4 Argyris suggests that

the autocratic leader expects his subordinates to provide minimal control over their workaday world, to be passive and denendent, to have a short time perspective, and to have shallow abilities. 5 Moore calls the autocratic leader an inner directed manager. He suggests the inner directed manager is characterized by being

"interested primarily in developing neat, logical,
efficient work systems and proceedures.... There is
one, and only one, best way to get the job done....
Building an organization represents a gradual but
consistent unfolding of the fundamental and inexor-
able logic of the one best system.... Since the system
is held to represent the one best way of getting the
job done, it is imperative to follow it exactly and
permit no deviations. Cooperation and ccordination
of human effort is built into the system so that,
if each individual performs his part of the total
task as it is supposed to be performed, then the
total effort will be harmonious, efficient, and
unified.... Control and design of the system becomes
management's main tasks. There can be only one
system and this must be guaranteed through the high-
est authority of management.... With the need of
close control, there is also the need for many
layers of supervision.... There is also a demand for
detailed reports and information regarding each
step in the work process and more or less constant
control....Following the system appears to become
more important than oyer-all results to management
and employees alike."

Next on the continuim this study places leadership style that allows input before the leader makes the decision. This type of leadership is self-explanatory.

4 Anthony Athos and Robert E. Coffey, Behavior in Crganizations: $\dot{H}$ Multidimensional View, (Englewood Cliffs: Frentice Hall, 1968), p. 163.

${ }^{5}$ Chris Argyris, Personality and Organization: The Conflict Between System and the Individual, (New York: Harper and Erothers, 1957), p. 66.

6David G. Moore, "Human Relations in Organization", in Concepts and Issues in Administrative Behavior, edited by Sidney Nailick, (Englewood Cliffs: Prentice Hall, 1962), p. 197. 
Then or the continuim this study claces the democratic leadership style. "The democratic leader draws ideas and suggestions from his followers and encourages them to participate in things that concern them. In some cases, he may let the group determine policy; in others he may ask their advice but make the final decision himself.? The democratic leader holds to the philosophy that "management is the development of people and not the direction of things." 8 Moore calis the democratic leader the other directed manager. The other directed manajer holds the conviction "that those closest to the scene of action can make certain more appropriate and valid decisions than the higher levels of authority." 9

At the other end of the continuim this study places the laissezfaire style of leadership. Laissez-faire leadership is characterized by ar absence of supervision or influence. "... When neither the supervisor nor the eroup member has substantial influence on a matter of organizational relevance, the supervisory style may be called one of abdication. Very little leadership occurs at all..."10 "The frcerein leader plays down his role in the group's activities and acts primarily to provide information, materials, and facilities for the group in accomplishing its objectives. He exercises a minimum of control."11

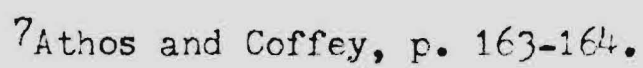

${ }^{8}$ Sister Helen Paula Grant, The Influence of Tradition on the Frocess of Crganizational Change, (Portland, Oregon: MSN practicum Portland State University, 1970), p. 6.

Noore, p. 199.

10 Hunt and Larson, p. 68.

${ }^{11}$ Athos and Coffey, p. 164. 
This conceptual continuim of leadership styles, wjth points for authoritarian, democratic, and laissez-faire leadership styles, enables this study to explore leadership styles in nursing homes and place them along this hypothetical continuim. This conceptual construct of a continuim of leadership styles is a basic assumption of this study. Conceptualizing this continuim does not suggest that pure organizational forms exist. On the contrary, "pure organizational forms do not exist in the real world."12 However, conceptualizing this continuim is one way of examing leadership styles.

\section{REVIE $A$ OF THE IITARATLRE}

A number of studies examine the leadership role. In reviewing the Iiterature, Argyris suggests that "successful employee-centered supervisors who were liked by the employees had supervisors who: 1) Let them participate in decision making. 2) Let them know what he thinks of their work. 3) Frequently ask him for his opinion."13 Likert in another review of the Iiterature states "supervisors with the best records of performance focus their primary attention on the human aspects of their subcrdinates' problems and on endeavoring to build effective work groups with high performance goals." 14 Likert draws this conclusion from the results of several different studies of

12 Charles F. Grosser, New Directions in Community Crganization, (New York: Praeger, 1973), p. 128.

13 Argyris, p. 190.

14 Rensis Likert, New Fatterns of Management, (New York: NcGraw Hill, 1961), p. 7 . 
different types o: work situations includine siericai, sajes, and manufacturing occupations. (Eose 1957; Ganguli 1957; Käln 1956; Katz and Kahn 1951 and 1952; Katz, Naccoby and Morse 1950; Likert and Willits $1940) .15$

"Ferhaps the most persistent and thoroughly demonstrated difference between successful and unsuccessful leacership... has to do with the distribution or sharing of the laadership functicn." (Katz and Kahn 1966):.6 Litwin's study (19,68) surgests that an authoritarian structured organization results in 10 job satisfactior, $10 \mathrm{w}$ performance, and a high level of power performance; while a democratic organization results in a high level of affiliation, high level of motivation, high job satisfaction, innovative performance, and overall low production. Tris same study distinguishes a teamwork management approach with the administrator making the decisions ard suggests that this approach results in innovative performance, high satisfaction,high motivation, high productivity, and high perceived efficiency.

In studying democratic leadership Campbell (1952) reports that shared leadership increases cohesiveness, productivity, iob satisfaction and morale, a broader time perspective, and greater flexibility in behavior. At the same time democratic leadership decreases the amount of interpersonal hostility, frustration, aggression, complaints, degree of dependence and submissiveness, and the need for scapegoats. Positive findings about democratic leadership style are also suggested by McCormick and Green $(1938,1953)$. McCormick and Green's study reports

15Iikert, p. 7 .

16D. Katz and R. L. Kahn, The Social Psychology of Crganizations, (New York: Wiley, 1966), p. 331-332. 
that self-control by employees increases production and decreases absenteeism and job turnover.

Other research suggests that more effective supervisors tend to look at long range goals, spend more time on motivational goals, and give their employees freedom and self-responsibility. (Whyte 1953, Mann and Dent 1954, Zaleznik 1956, Baumgartel 1956, Katz 1951). Argyris (1954) reports that the employees' degree of morale increases as the degree of directive leadership decreases. Bhushan (1971) reports democratic leadership is preferred by employees over ambiguous or authoritarian leadership.

A number of studies have focused on leadership style and productivity. The findings suggest that production is higher when the supervisor is democratic and open to employee participation in making decisions. (Kahn 1958, Coch and French 1948, Guest 1962). Morse and Reimer (1959) state that "building productivity through participative methods is a longer process, but likely to be more lasting."17 "Research indicates that supervisors who devote themselves exclusively to production matters and the observance of routine institutional duties are not the heads of high-producing groups nor of groups with high morale." $(\mathrm{Pelz} 1949)^{18}$

The findings of a study by Barnes (1960) questions the usefulness of management orientations that stress profits, productivity, and

${ }^{17}$ Paul Pigors and Charles Myers, Personnel Administration, (New York: McGraw Hill, 1951), p. 21.

${ }^{18}$ Daniel Katz, "Human Relationships and Organizational Behavior", in Concepts and Issues of Administrative Behavior, edited by Sidney Mailick, (Englewood Cliffs: Prentice Hall, 1962), p. 183. 
practicality to the exclusion of other values. This study finds no relationship between high performance and job satisfaction. However, the study suggests that the more open system encouraged less constraint, greater autonomy, more interaction, and more upward influence. "The relatively open system apparently accompanies a less rigid social structure, less status consciousness, and higher satisfaction."19 Barnes states that productivity cannot be compared accurately in this study, however management is more satisfied in an open system.

In a closed system Barnes suggests that individuals may be rewarded artificially for status rather than for actual work contributions. The closed system may also generate competition, controls, and interactions that separate management's logics from subordinates needs and contributions. "Barnes study and others suggest that whenever people feel they can get the help they need to do a good job, and when they can grow because of what they do at work, their basic needs - as human beings - can motivate them to make an all-out effort toward organizational goals. ${ }^{20}$

Other research focuses on laissez-faire leadership. "We know from experiments and field research that laisezz-faire leadership creates more tension and anxiety than does either democratic or autocratic." Kelly (1970) reports that individuals prefer active versus passive leadership techniques in development groups. This seems to be true of employees in organizations also. (Vujtech 1971). Lippit and

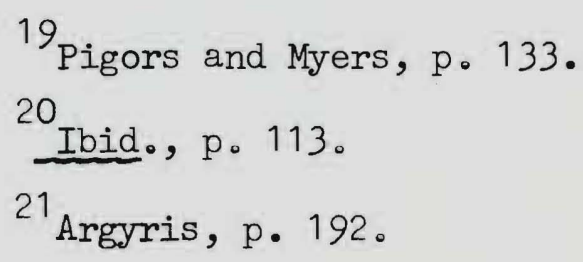


Bradford (1945) report that individuals experience greater frustration, failure, and insecurity with laissez-faire leadership than with any other style of leadership.

Other research seems to contradict some of the previously mentioned studies. Catell, Saunders, and Stice (1953) report that democratic leadership is not a solution and that the situation is much more complicated than that. Other studies suggest "no really substantial, reliable, or general correlation between satisfaction and productivity." (Bayfield and Crockett 1955; Herzberg, Mausner, Peterson, and Capwell 1957; Kahn 1960; Opsahl and Dunnette 1966; Smith and Cranny 1968; Vroom 1964). ${ }^{22}$ Haythorn, Couch, Haefner, Langhan, and Carter (1956) concur that democratic leadership is not the solution and that factors such as match between leader and members styles, and task demands are important considerations.

Another facet of leadership style that has been researched involves examining the impact of supervisors who consider their employees as individuals rather than as a means to production. Studies indicate that this dimension effects employees in a positive direction (Likert and Willits 1940, Morse 1953).

Leadership styles are also examined in terms of the effect on clients. For professional work a positive relationship exists between job satisfaction and performance. Hoppock 1935, Super 1939, and Blau 1964 report the more democratic the supervisor the more client oriented

${ }^{22}$ Patricia Cain Smith, Lorne M. Kendall, and Charles L. Hulin, The Measurement of Satisfaction in Work and Retirement: A Strategy for the Study of Attitudes, (Chicago: Rand McNally, 1969), p. 3. 
the subordinates. Also conflicts among staff members seem to result in a negative consequence for clients (Caudill 1958, Stanton and Schwartz 1954).

Turning to nursing home settings, Sydnor and Wold (1974) report the security that the institutionalized elderly feel regarding the care they receive is positively associated with their morale. ${ }^{23}$ The literature reveals few studies that focus on leadership styles in service delivery systems and none this researcher is aware of that focus on leadership styles in nursing care facilities.

\section{QUESTIONS TO BE EXPLORED}

The questions to be explored in this study center around leadership style, staff satisfaction, and patient satisfaction in nursing home settings. Specifically, what is the relationship between leadership style and staff satisfaction in nursing homes? What is the relationship between leadership style and patient satisfaction? Is staff satisfaction related to patient satisfaction?

The hypothesis to be explored in this study are:

1. Staff satisfaction is positively correlated to staff perception of the leadership as democratic.

2. Staff perception of the management being oriented to people as individuals is positively correlated to staff satisfaction.

3. Staff perception of the leadership as democratic is positively

${ }^{23}$ Gail 0lmstead Sydnor and Patricia Mears Wold, Some Correlates of Morale Among Nursing Home Residents, (Portland, Oregon: MSW practicum Portland State University, 1974), p. 34 . 
correlated to staff perception of the management being oriented to people as individuals.

4. Patient satisfaction is positively correlated to the perceived democratic leadership style.

5. Patient perception of the management being oriented to people as individuals is positively correlated to patient satisfaction.

6. Staff satisfaction is positively correlated to patient satisfaction.

7. Staff and patient perceived harmony among the staff is positively correlated to patient satisfaction. 
CHAPTER II

METHODOLOGY

A. THE SELECTION OF NURSING HOMES

For this study a number of nursing homes were randomly selected from a listing of nursing facilities in the Portland, Oregon metropolitan area that serve approximately 100 or more patients. The administrators of these homes were then contacted, first by phone and then in person, to discuss their possible participation in this study. Seven nursing home administrators were contacted in this manner.

Three of the seven administrators declined to participate in the study. One of the administrators declined to participate due to scheduling conflicts. The other two who declined expressed concerns about the possible negative reactions the staff and patients might have if they participated in the study. One administrator stated that staff should never be placed in a position of evaluating management because staff are unqualified to judge leadership ability and unaware of what is involved in the operation of an organization. Other fears expressed concerned possible stimulation of staff unrest leading to unionism, infringement of patients' right to privacy, and undermining of supervisors. Other comments about the study included the questionaire is too long, the study suggests change which would not be forthcoming, the questions suggest a negative response, and the writing down of an opinion makes that opinion difficult to change and in a sense makes that opinion a commitment to a belief.

Four nursing home administrators agreed to participate in the 
study. One of the four had strong objections to patients being interviewed due to unfavorable past experiences where patients were confused and troubled after a survey experience. The hesitation of administrators to allow the interviewing of patients and the time restrictions of this study led to the decision to eliminate this portion of the study.

\section{B. DESCRIPTIONS OF HOMES}

The study includes four nursing care facilities, ranging in time of operation from six years to fifty years, with two facilities private agencies, one sectarian nonprofit, and one public ownership. Two of the facilities are located in urban settings. One facility is located in an upper middle class suburban setting and one facility is located in a suburban/rural setting.

Two of the four administrators have medical backgrounds. One administrator has a business background and one has a religious background. Three of the facilities are certified for intermediate or semi-skilled nursing care, and residential care. One of the facilities is certified for skilled nursing care, intermediate or semi-skilled care, and also has five residential care patients (five residential care patients or under does not require certification).

The total patient population per home ranges from 94 patients to 173 patients. Welfare patients per home are 10 percent, 20 percent, 90 percent, and 95 percent of the total patient population. The average private patient fee for each of the four facilities for intermediate or semi-skilled care is $\$ 565.20$ a month, $\$ 604.50$ a month, 
$\$ 690.00$ a month, and $\$ 750.00$ a month.

The four nursing homes range from forty-nine staff positions to ninety-seven staff positions. Three of the four have staff/patient ratios of one staff position to two patients. One facility has one staff position fo three patients. All of the nursing homes in this study use part time help in some degree; however, one of the nursing homes relies heavily on part time help and hence has more staff per staff positions.

A great variation in staff positions exist between the four nursing homes. In addition to registered nurses, licensed practical nurses, nurse aides, and ancilary staff, two of the four nursing facilities employ full time physical therapists. Two of the four employ full time activity directors. One of the facilities employs a full time dietitian, a full time occupational therapist, and a full time social service worker.

All four nursing care facilities used in this study employ consultants to meet part of their needs. However, the type of consultant employed and the hours used varies considerably between the four facilities. Two of the four homes use the services of a physical therapist consultant (six hours a month and four hours a month). Three of the facilities employ dietitian consultants (sixty-four hours a month, four hours a month, and three hours a month). Two of the homes employ occupational therapist consultants (five hours a month and four hours a month). Two of the four employ a medical records consultant (eight hours a month and four hours a month). Two of the four employ pharmicists ( 100 hours a month and 100 hours a month). One of the four employs a speech therapist consultant (twenty-four hours a month). One 
of the four facilities reports a medical doctor as a consultant (thirty hours a month). One of the four reports a psychiatrist consultant (sixteen hours a month). One facility reports using a social work consultant from different sources ( a welfare social worker eight hours a month, a Veterans' social worker two hours a month, and a private social worker two hours a month). In addition, one of the facilities has a four day a week beauty operator.

Differences between facilities in the staff's length of time with the agency, education, and age, are also evident (Appendix A). The many differences between the four homes are not viewed as a liability to this study as the study is not a comparison of the four facilities. The differences are hence viewed as interesting side issues and are not dealt with in this paper.

\section{THE SAMPLE}

A sampling of staff from each of the four facilities was selected with the approval of the administrators of two of the nursing care facilities and with the approval of the assistant administrators of two of the facilities. Care was taken to insure the sample would include three levels of staff: administrative, supervisory, and line staff. Staff from all departments including health care, maintainance, kitchen, and clerical, were included. The sample from the health care department includes staff from the day, swing, and graveyard shifts. The study aimed for a sampling of half of each facility but compromised with the nursing homes when necessary.

The sample from nursing home A included the administrator, three 
of the ten non-nurse professionals, five of the thirteen ancilary staff positions, the director of nurses, six of the twelve health care staff day shift including supervisors, three of the eight health care staff swing shift including supervisors, and three of the five health care staff graveyard shift including supervisors. The sample from nursing home $B$ included the administrator, three of the seven ancilary staff positions, three of the seven maintainance department positions including the supervisor, five of the twelve housekeeping department positions including the supervisor, eleven of the twenty-three kitchen staff including the supervisor, the director of nurses, eight of the fifteen health care staff day shift including supervisors, seven of the twelve health care staff swing shift including supervisors, and seven of the seven health care staff graveyard shift including supervisors.

The sample from nursing home $\mathrm{C}$ included the assistant administrator, the one ancilary staff position, five of the ten kitchen staff including the supervisor, two of the five housekeeping staff, the director of nurses, seven of the sixteen health care staff day shift including supervisors, one of the nine health care staff swing shift, and one of the six health care staff graveyard shift. The sample from nursing home $\mathrm{D}$ included the administrator, the assistant administrator, one of the three ancilary staff positions, three of the three laundry department staff including the supervisor, six of the sixteen kitchen staff including the supervisor, eleven of the twenty-six health care staff day shift including supervisors, eight of the eighteen health care staff swing shift including supervisors, and four of the ten health care staff graveyard shift including the supervisor. 


\section{THE SCHEDULE}

"The two major methods of learning systematically about employee attitudes are the questionaire and the interview. Of the two, the questionaire is most widely used. The questionaire method is less expensive, requires fewer trained personnel, and is not subject to such drawbacks as the personal biases of the interviewer." 24 Hence the schedule or attitude survey method of obtaining data was selected for this study.

"The objectives of the attitude survey are 1) to determine what is important within the environment to the employee; 2) to determine the degree to which managers meet the human needs of the organization; 3) to pinpoint the specific strong and weak points of company policies and practices; 4) to evaluate the company's physical facilities and working conditions; 5) to find out what employees feel and think; and 6) to determine information and training needs. Subsidiary objectives are the release of tension through the expression of dissatisfactions and the expression by management of concern, if nothing else, about what the employees feel and think."25 This study's schedule attempts to address some of these areas.

The original intent of the study was to create an attitude survey that could be administered to the staff and patients of nursing homes. Hence, the questions were designed to be as applicable to patients as to staff (Appendix C).

24pigors and Myers, p. 288-289. ${ }^{25}$ Ibid., p. 288. 
Questions one through four were constructed to elicit biographical information about the respondent: position with the agency, length of association with the agency, highest level of education completed, and age. Questions five and six explore degree of satisfaction with the agency and satisfaction with personal treatment at the agency. The perceived amount of participation in decision making allowed at the agency and hence the style of leadership at the agency is explored in questions seven through ten. Questions eleven through thirteen elicit information concerning perception about how capable and willing people are to make decisions, and hence an indicator of leadership style on a philosophical level。 Questions fourteen and fifteen explore the perceived harmony at the agency. Questions sixteen elicits perception about the management's philosophy and hence leadership style at the agency. Question seventeen elicits information concerning perception of being treated as an individual with feelings and hence perception of leadership style at the agency. Space was provided for comments.

\section{E. THE PROCEEDURE}

Questionaire schedules that could be quickly self-administered by all levels of staff were left with the designated nursing home representative (administrator or assistant administrator) with a specific guideline as to how many staff from each department and each shift needed to participate. A cover sheet guideline for participating staff was included with each questionaire schedule (Appendix B)。

All questionaires were adminstrated within a three week period of time. During this time period one of the nursing care facilities 
changed ownership. The effects of the change of ownership on this study are unknown. Another one of the facilities is currently experiencing uncertainty concerning the continuation of public funding and hence possible closure. The effects of the uncertainty on the respondents from this facility, and hence the effect on this study, is also unknown.

The responses for the non-biographical section of the schedule were coded: 1 for strongly agree, 2 for moderately agree, 3 for neutral, 4 for moderately disagree, and 5 for strongly disagree. The coded material was transferred to IBM cards and verified for computer processing. A computer consultant suggested the Statistical Package for the Social Sciences which includes frequences(mean, variance, and standard deviation), crosstabulations ( chi square), and nonparametric measures (Spearman Correlation).

\section{F. THE RESPONSES}

Respondents generally answered all of the questions with few exceptions. However, one of the facilities did not return a significant number of questionaires from the swing and graveyard shifts of the health care department.

Most of the responses in all four facilities were on the positive side of the five point scale (Appendix D). Nursing home A in particular had few negative responses. However, the degree of positive responses varies between the homes as indicated by the percentages.

Two of the four facilities seemed more free to respond with optional comments with 20.5 percent and 24.2 percent submitting comments 
compared to the 9.1 percent for the other two facilities. Comments varied greatly from congratulating this researcher on obtaining a master degree to explaining the reason for answering a question a certain way, to giving additional information about the nursing home. 
CHAPTER III

RESULTS

\section{A. ANALYSIS AND FINDINGS}

Frequencies, crosstabulations, and non-parametric correlations were computed, using the Statistical Package for the Social Sciences, for the purpose of determining relationships and significance among variables.

First the data was examined in terms of frequencies: mean, the arithmatic average of the responses to each question; variance, the dispersion of the responses about the mean; and standard deviation, the dispersion of the responses about the mean (the square root of the variance). The data reveals facility A reports a high degree of homogeniety in answering the questions, the variance is quite low (Table 1). Only two of the thirteen questions have a variance of 1.000 or over on an answering scale of one to five. The average response to most of the questions was moderately agree. Moderately agree to neutral was the average response regarding general satisfaction here, people capable of decisions here, leadership allows input, friendly atmosphere here, and people get along well here. The average response in this facility was neutral to moderately disagree regarding perception of leadership as autocratic. A marked distinction between the perceived leadership style is not indicated, but rather a gradual gradation from perceived laissez-faire leadership with a mean of 2.091 (moderately agree), to perceived democratic leadership with a mean of 2.182 (moderately agree), to perceived leadership allows input with a mean of 2.400 (moderately agree to neutral), to perceived autocratic leadership with a mean of 
Table 1: Home A Frequencies

$$
n=22
$$

\begin{tabular}{|c|c|c|c|}
\hline Variablo & Mean & Variance & S.D. \\
\hline General Satisfaction Here & 2.273 & .303 & .550 \\
\hline Satisfaction Way Treated Here & 1.955 & .426 & .653 \\
\hline Perceived Laissez-faire Leadership & 2.091 & .753 & .868 \\
\hline Perceived Democratic Leadership & 2.182 & 1.013 & 1.006 \\
\hline Perceived Loadership Allows Input & 2.400 & .989 & .995 \\
\hline Perceived Autocratic Leadership & 3.500 & 1.405 & 1.185 \\
\hline People Capable of Making Decisions & 2.238 & .390 & .625 \\
\hline Peoplo Don't Want Responsibility & 2.136 & .695 & .834 \\
\hline People Capable of Decisions Here & 2.591 & .729 & .854 \\
\hline Friendly Atmosphere Here & 2.409 & .348 & .590 \\
\hline People Get Along WeIl Here & 2.636 & .719 & .848 \\
\hline $\begin{array}{l}\text { Philosophy of Management } \\
\text { Oriented to People }\end{array}$ & 2.00 & .667 & .816 \\
\hline Feel Treated as a Person & 2.091 & .468 & .684 \\
\hline
\end{tabular}

Coded 1=strorgly agree, $2=$ moderately agree, $3=$ neutral, 4=moderately disagree, 5=strongly disagree 
3.500 (neutral to moderately disagree).

Nursing home B reveals a lower degree of homogeniety in answering the questions than does facility A (Table 2). Six of the thirteen questions have a variance of 1.000 or over on a scale of answers of one to five. The average response in facility $B$ to eight of the thirteen questions was strongly agree to moderately agree. The average response was strongly agree to satisfaction with the way treated here, philosophy of the management is oriented to people, and feel treated as a person here. Moderately agree to neutral was the average response to people don't want responsibility. Nursing home B respondents perceived leadership as allowing input before making the final decision himself with a mean of 1.698 (strongly agree to moderately agree), perceived democratic leadership with a mean of 1.744 (moderately agree), perceived laissez-faire leadership with a mean of 1.795 ( moderately agree), and perceived autocratic leadership with a mean of 4.093 (moderately disagree).

Nursing home $\mathrm{C}$ has even less agreement in answering the questions than does either facility A or B (Table 3). Nine of the thirteen questions have variances of over 1.000 on a scale of answers of one to five. Again the average of the responses is moderately agree with the exceptions of perceived autocratic leadership and people don't want responsibility. As with nursing home A, perceived leadership styles are ranked from laissez-faire with a mean of 2.00 (moderately agree), to democratic with a mean of 2.045 (moderately agree), to leadership allows input before making decisions with a mean of 2.182 (moderately agree), to autocratic leadership with a mean of 3.864 (moderately disagree). 
Table 2: Home B Frequencies

$n=44$

\begin{tabular}{|c|c|c|c|}
\hline Variablo & Mean & Variance & S.D. \\
\hline General Satisfaction Here & 1.727 & .668 & .817 \\
\hline Satisfaction Way Treated Here & 1.295 & .353 & .594 \\
\hline Perceived Laissez-faire Leadership & 1.795 & 1.097 & 1.047 \\
\hline Perceived Democratic Leadership & 1.744 & 1.385 & 1.177 \\
\hline Perceived Leadership Allows Input & 1.698 & 1.264 & 1.124 \\
\hline Porceived Autocratic Ieadership & 4.093 & 1.753 & $1.324_{4}$ \\
\hline Peoplo Capable of Making Decisions & 2.070 & .590 & .768 \\
\hline People Don't Want Responsibility & 2.341 & 1.486 & 1.2 .29 \\
\hline People Capable of Decisions Here & 2.233 & 1.087 & 1.0143 \\
\hline Friendly Atmosphere Here & 1.614 & .429 & .655 \\
\hline Peoplo Get Along WeII Here & 1.860 & .551 & .743 \\
\hline $\begin{array}{l}\text { Philosophy of Management } \\
\text { Oriented to People Here }\end{array}$ & 1.182 & .292 & .540 \\
\hline Feel Treated as a Person Here & 1.273 & .389 & $.62 L_{4}$ \\
\hline
\end{tabular}

Coded 1=strorgly agree, $2=$ moderately agree, 3 =neutral, 4=moderately disagree, 5=strongly disagree 
Table 3: Home C Frequencies

$$
n=22
$$

\begin{tabular}{llll} 
Variable & Mean & Variance & S.D. \\
\hline General Satisfaction Here & 2.091 & 1.039 & 1.019 \\
Satisfaction Way Treated Here & 1.909 & 1.325 & 1.151 \\
Perceived Laissez-faire Ieadership & 2.00 & 1.333 & 1.155 \\
Perceived Democratic Ieadership & 2.045 & 1.284 & 1.133 \\
Perceived Ioadership Allows Input & 2.182 & 1.584 & 1.259 \\
Perceived Autocratic Ieadership & 3.864 & 1.361 & 1.167 \\
People Capable of Making Decisions & 2.091 & .994 & .971 \\
People Don't Want Responsibility & 2.727 & .970 & .985 \\
People Capable of Decisions Here & 2.136 & .790 & .889 \\
Friendly Atmosphere Here & 1.909 & .848 & .921 \\
People Get Along Well Here & 2.00 & 1.238 & 1.113 \\
Philosophy of Management & & & 1.019 \\
Oriented to People Here & 1.909 & 1.039 & 1.016 \\
Feel Treated as a Person Here & 1.955 & 1.093 &
\end{tabular}

Coded 1=strongly agree, 2=moderztely agree, 3=neutral, 4=moderately disagree, $5=$ strungly disagree 
Nursing home $D$ has even less consensus in answering the questions than any of the other facilities in this study (Table 4). Variance in twelve of the thirteen questions is over 1.000 and variance on one question is over 2.000 on a scale of one to five. The average response to most questions is moderately agree to neutral. Perceived leadership styles are ranked from laissez-faire with a mean of 2.188 (moderately agree), to leadership allows input with a mean of 2.485 (moderately agree to neutral), to democratic with a mean of 2.515 (moderately agree to neutral), to autocratic with a mean of 3.485 (neutral to moderately disagree).

The second and third portions of the computer program examined the data for cross tabulations (chi square), checking if a relationship exists between two variables; and non-parametric correlations (Spearman Correlation), checking the strength of a relationship (Table 5). In two of the four facilities a relationship exists at the .05 level of significance between the general satisfaction of the stafi and the staff perceiving the leadership style as democratic. In these two facilities this relationship between satisfaction of the staff and perceived democratic leadership is statistically significant in strength at the .05 level of significance. In three of the four facilities a relationship exists between staff satisfaction in the way they are treated at the facility and the staff's perception of the leadership style as democratic. In these three facilities the relationship between the staff's satisfaction in the way they are treated and the staff's perception of the leadership as democratic is statistically significant in terms of the strength of the relationship. 
Table 4: Home D Frequencies

$$
\mathrm{n}=35
$$

\begin{tabular}{llll} 
Variable & Mean & Variance & S.D. \\
\hline General Satisfaction Here & 2.455 & 1.568 & 1.252 \\
Satisfaction Way Treated Here & 1.879 & 1.235 & 1.111 \\
Perceived Laissez-faire Leadership & 2.188 & 1.577 & 1.256 \\
Perceived Democratic Leadership & 2.515 & 1.758 & 1.326 \\
Perceived Leadership Allows Input & 2.485 & 2.070 & 1.439 \\
Perceived Autocratic Leadership & 3.485 & 1.883 & 1.372 \\
People Capable of Making Decisions & 2.219 & .951 & .975 \\
People Don't Want Responsibility & 2.516 & 1.191 & 1.092 \\
People Capable of Decisions Here & 2.091 & 1.273 & 1.128 \\
Friendly Atmosphere Here & 2.129 & 1.249 & 1.118 \\
People Get Along Well Here & 2.212 & 1.297 & 1.139 \\
Philosophy of Management & & & \\
Oriented to Peoplo Here & 2.091 & 1.835 & 1.355 \\
Feel Treated as a Person Here & 2.091 & 1.335 & 1.156 \\
\hline
\end{tabular}

Coded 1=strongly agree, 2=moderately agree, 3=neutral, 4=moderately disagree, 5=strongly disagree 
A relationship exists in two of the four nursing homes between general satisfaction of the staff and philosophy of the management is oriented to people. This relationship is statistically significant in terms of the strength of the relationship. General satisfaction and feeling treated as a person indicated a relationship exists in three of the four nursing homes. This relationship is statistically significant in terms of the strength of the relationship. Staff's satisfaction with the way they are treated and the perceived philosophy of the management as being oriented to people is a significant relationship in three of the four nursing homes. The strength of this relationship is statistically significant. The staff's satisfaction with the way they are treated and feeling treated as a person is a significant relationship in all of the facilities. The strength of this relationship is statistically significant in all of the nursing homes in this study. The staff's perception of the leadership as democratic and their perception of the philosophy of management is oriented to people is a significant relationship in all of the facilities. This relationship is significantly strong statistically in three of the four facilities. The staff's perception of the leadership as democratic and feeling treated as a person is significant in three of the four facilities. The relationship is significantly strong.

Several other styles of leadership significantly correlate with general satisfaction, satisfaction with way treated, management philosophy, and treated as a person (Appendix E). However, none of the leadership styles are as consistent in terms of the existence and strength of relationships, with the variables listed above, as is the democratic style of leadership. Although three of the four homes 
Table 5: Crosstabs and Non-parametric Correlations

Variąblo

Chi Square

Spearman

Home $A, n=22$

$\begin{array}{lll}\text { General Satisfaction/Democratic Leadership } & 4.71129 & .3265 \\ \text { Satisfaction Treated/Democratic Leadership } & 12.67821 * & .5945 * \\ & & \\ \text { General Satisfaction/Management Philosophy } & 6.875 & .5271 * \\ \text { General Satisfaction/Treated as Person } & 5.2381 & .3385 \\ \text { Satisfaction treated/Management Philosophy } & 7.84959 & .4533 * \\ \text { Satisfaction Treated/Treated as Person } & 17.08526 * & .5333 * \\ & & \\ \text { Democratic Ioadership/Management Philosophy } & 17.08929 * & .8119 * \\ \text { Democratic Ieadership/Treated as Person } & 12.46667 & .6561\end{array}$

Home B, $n=44$

$\begin{array}{lll}\text { General Satisfaction/Democratic Ieadership } & 21.80977 * & .3522 * \\ \text { Satisfaction Treated/Democratic Leadership } & 44.00781 * & .7708 *\end{array}$

General Satisfaction/Management Philosophy $\quad 2.7360 \quad .1076$

General Satisfaction/Treated as Person 30.2628* .2916*

Satisfaction Treated/Management Philosophy 13.17965* .4106*

Satisfaction Treated/Treated as Person 59.49714* .6422*

Democratic Ieadership/Management Philosophy 57.68973* .4559*

Democratic Ieadership/Treated as Person $47.68845 \% \quad .7185 \%$

*These figures applied to a standardized table at certein degrees of freedom are significant at a .05 level. 
Table 5: Crosstabs and Non-parametric Correlations

Variablo

Chi Square

Spearman

Home $C, n=22$

General Satisfaction/Democratic Loadership $47.81481 *$

$.6696 *$

Satisfaction Treated/Democratic Leadership $46.2 \%$

$.6990 *$

General Satisfaction/Management Philosophy

General Satisfaction/Treated as Person

$22.00 *$

$23.3750 *$

Satisfaction Treated/Management Philosophy

$22.69667 *$

Satisfaction Treated/Treated as Person

$41.80 \%$

$.5990 *$

$.5202 *$

$.4752 \%$

$.8418 \%$

Democratic Leadership/Management Philosophy 26.70556* .3392 Democratic Ieadership/Treated as Person 28.16628* .6150*

Home $D, n=35$

General Satisfaction/Democratic Leadership $24.15417 \quad .3766 *$

Satisfaction Treated/Democratic Ioadership $24.08309 \quad .3775^{*}$

General Satisfaction/Management Philosophy 65.21181* .5401*

General Satisfaction/Treated as Person 55.93561* .5843\%

Satisfaction Treated/Management Philosophy 64.89583* .5328*

Satisfaction Treated/Treated as Person 76.08283* .7491*

Democratic Ieadership/Management Philosophy 27.27185* .3187* Democratic Ioadership/Treated as Person 27.10603* .5973*

*These figures applied to a standardized table at certain degrees of freedom are significant at a .05 level. 
perceived leadership as being a laissez-faire style, democratic leadership has more frequent and stronger relationship with these variables.

In summary, the major findings are:

1. Staff satisfaction about the way they are treated is positively correlated to staff's perception of the leadership style as democratic.

2. Staff satisfaction about the way they are treated is positively correlated to staff's perception of the philosophy of the management as being oriented to people.

3. The staff's satisfaction with the way they are treated is positively correlated to feeling treated as a person with feelings.

4. The staff's perception of leadership as democratic is positively correlated to staff's perception of the philosophy of management as oriented to people.

5. Staff's perception of the leadership style as democratic is positively correlated to staff feeling treated as a person.

\section{B. LIMITATIONS}

An in-depth review of the literature revealed no research on staff satisfaction or patient satisfaction as related to leadership style in nursing care facilities. Hence this study is an attempt to apply industrial/business attitude survey questions to a social service setting. Ideas were borrowed from a number of different studies. No pretest was done. As a result this researcher was unaware until the completion of the study that the questions on leadership style do not 
clearly delineate between different styles of leadership. Differences in the degree of perceived leadership styles can be observed in the results, but not a clear distinction.

Issues other than leadership styles which might relate to staff satisfaction were not examined in this study. For example, pay scales, employee benefits, physical surroundings, and hours worked were not considered in this study. Organizational issues such as lines of communication, clarity of job roles, grievance proceedures, training proceedures, lines of authority, lines of responsibility, and methods of motivation were not examined.

The nursing care facilities portrayed in this study are not necessarily representative of nursing homes in general. This researcher suspects the four nursing homes in this study are generally above average in terms of services delivered and working conditions for the staff. The findings cannot therefore be indiscriminately applied to all nursing homes. The responses are probably skewed in a positive direction.

As already mentioned, two of the facilities used were undergoing changes at the time the data was collected. The effects of these changes on this study is unknown.

\section{SUGGESTIONS FOR FURTHER RESEARCH}

This study indicates that democratic leadership is positively correlated with staff satisfaction in four nursing home settings. Unfortunately this study was unable to examine the relationship of 
patient satisfaction and leadership style and the relationship of patient satisfaction and staff satisfaction as originally intended. With this additional information some comments could be made concerning leadership style and service delivery systems as perceived by recepients. This researcher strongly suspects a positive correlation between democratic leadership style and patient satisfaction and between staff satisfaction and patient satisfaction in nursing care facilities.

Several theoreticians support this viewpoint. Whitehead suggests and Barlow agrees, "an efficient service for the elderly can be developed with the present facilities, provided someone in each area commits himself to its organization, and utilizes techniques that result in other staff becoming involved and committed. These include breaking down narrow concepts of role, the use of regular staff meetings where information can be exchanged, fears and anxieties ventilated and an opportunity provided for everyone to contribute, coupled with an organization which allows staff to implement their own ideas and be responsible for them." 26 Whitehead continues to say that with authoritarian style of leadership, "patients are always seriously affected. Their freedom is liable to restriction, deviant behavior is punished, ill-usage covered up, out-dated methods of treatment continued, and : ail the conditions productive of institutional neuros: fostered." 27 Tobin adds to this by writing, "the administrative hierarchy ${ }^{26}$ Anthony Whitehead, In Service of 0ld Age: the Welfare of Psychogeriatric Patients, (Baltimore, Maryland: Penguin Books, 1970), p. 146. 27 Ibid., p.25. 
also influences tre interactions of staff and resident. The working rolationsuip between diroctor and associate director, for exanple, is usually perceived, or felt by t.e rosident ard t.is infiuences treir interpersonal interactions. The new resident will usually learn the network of these staff relationsilips tirougil tie older residents with whom they tend to relate as siblings. This learning is part of tne initial adaption process in which tre new residont is taught 'who is who' and how to relate to a variety of authority figures. "28

Barnes writes, "...an organizational system ielps or ninders an individual to meet his self-esteem needs by tre extent of autonomy and freedom it provides on tile job. It affects other-esteem by tile ways in wrich influence relationsiips are structured."29 Shore would ayree with this and suggest patients of nursing homes be accorded similiar autonomy and freedom. shore cites a nursing care facility where "opportunities are sougnt where a group of residents can think, discuss, plan, decide, act and evaluate together for tie purpose of attacking and solving a common problem affecting their lives." 30

Another issue for further research involves examining tile attitudes of administrators and supervisors in tems of their impact on the quality of social service. Kurtz states, "quality of service

${ }^{28}$ Sheldon S. Tobin, "Understanding tile IIderly" in Nursing and Retirement Home Administration, edited by $H$. Lee Jacobs and hoodrow $W$. Morris, (Ames, Iowa: Iowa State University Press, 1966), p.7.

29 Pigors and i.yers, p. 167 .

30 Herbert $H_{0}$ Shore, "Resident Participation in vieal Planning", in Selected Articles on Nursing homes, (Washingtor, D.C.: U.S. Department of H.L.W., 1960), p. 145. 
depends more upon attitudes and belief's (particularly tne attitudes and beliefs of the leaders, executive, suptrvisors, and jofessional workers) tuan upor efficiency of operation, important as efliciency may be." 31 Hooper also reports, "...tne administrator does mich to set tre tone of a nursing nome. His attitude and reactions to t: $€$ patients will usually carry over to trie stalf. If ti:e administrator is concerned about tue patient as an individual for example - acting as a catalyst in stimlating tre physician-in-charge, the nurses, and any otrer paranedical personnel (such as part-tine pnysical tre rapist working toward the rehabilitation of a stroke patient), the morale of the entire nursing home will improve. If, on tile other hand, he regards the patients only as a source of income and allows them merely to 'exist' and not to 'live', tne general atinosphere will be one of depression and despair. Sucn an attitude is detrimental, not only to the patients but also to tne staff, who would ratner work in more pleasant and nopeful surroundings." 32

A triird issue to research is tiat style of leaciersilip within an organization will tend to be homogenous. Litterer states, if "ihigh executives in an organization decicie, consciously or unconsciously, that it is not good for subordinates to get involved in decision making, this information probably will permeate tut organization quickly, and also act as a guide for subordinate managers in choosing

31 Russel it. hurtz, "Adrinistration of Nocial Agencies" in Social Work Yearbook, (New York: National Association of Social Workers, 1957) p. 76.

32 Langdon Hooper, Care of trie Nursing Home Patient, (Boston; Little, Brown and Company, 1967), p. 11-12。 
their own immediate leadership styles. The result will be that the leadership practices within the organization probably will tend to be homogenous." 33

A fourth issue that suggests research is the theory that peer group interaction of staff is positively correlated with meeting the clients' needs over meeting proceedural demands. 34

A final research issue is the theory that staff harmony will have a positive effect on residents of nursing homes. Baumgarten Jr. writes, "hostility between staff members will be reflected in fear or emotional disturbances by patients." 35 Actually any further research involving patient and staff satisfaction in nursing homes or client and staff satisfaction in any social service delivery system would be beneficial and help fill a void in the literature.

\section{IMPLICATIONS}

The message is clear, "the most effective way to get (positive) results in any organization is to work with people rather than through them." 36 In this study the positive results are limited to staff satisfaction. Hopefully further research will allow comments concerning leadership style and positive results in terms of service delivery systems. The message of working with people rather than through them

\section{${ }^{33}$ Litterer, p. 39.}

${ }^{34}$ Elihu Katz and Brenda Danet, Bureaucracy and the Public, (New

York: Basic Books Inc., 1973), p. 168 .

${ }^{35}$ Baumgarten, Jr., p. 135.

36 Pigors and Myers, p. 10. 
in this researcher's opinion can also be applied to nursing home residents. Situations can be created where patients can make decisions and have input into nursing homes.

What are the implications for practice? The hope of this study is to create an awareness that leadership styles have an impact on staff satisfaction and perhaps on patient satisfaction. Based on knowledge choices can be made to further the best interests of staff and residents of nursing homes.

Professionals working in nursing homes, especially social work consultants, can assist the facility in moving toward a more democratic style of leadership for staff and patients. Whitehead states, "the health service needs both worker and patient participation if it is ever to overcome its present difficulties and develop into a humane public service." 37 The same statement, in the opinion of this researcher, can be made concerning nursing care facilities.

${ }^{37}$ Whitehead, p. 22 . 


\section{BIBLIOGRAPHY}

Appley, Lewrence A., Values in Management, New York: American Management Association, 1969.

Argyris, Chris, Personality and Organization: The Conflict Between System and the Individual, New York: Harper Brothers, 1957.

Athos, Anthony, and Robert E. Coffey, Behavior in Organizations: A Multidimensional View, Englewood Cliffs, New Jersey: Prentice Hall, 1968.

Barlow, Alton E., "Building and Executing a Patient Care Plan", in Nursing and Retirement Home Administration, edited by H. Lee Jacobs and Woodrow W. Morris, Ames, Iowa: Iowa State University Press, 1966.

Baumgarten Jr., Harold, Concepts of Nursing Home Administration, New York: The MacMillan Company, 1965.

Grant, Sister Helen Paula, The Influence of Tradition on the Process of Organizational Change, Portland, Oregon: Portland State University, 1970.

Grosser, Charles F., New Directions in Community Organization, New York: Praeger Publishers, 1973, chapter 4.

Hall, Richard H., Organizational Structure and Process, Englewood Cliffs, New Jersey: Prentice Hall, 1972.

Hooper, Iangdon, Care of the Nursing Home Patient, Boston: Little Brown and Company, 1967.

Hunt, James G., and Lars L. Larson, Continuing Approaches to Leadership, Carbondale, Illinois: S. Illinois Press, 1974.

Katz, Daniel, "Human Relationships and Organizational Behavior," in Concepts and Issues of Administrative Behavior, edited by Sidney Mailick, Englewood Cliffs, New Jersey: Prentice Hall, 1962.

Katz, Daniel, and R. I. Kahn, The Social Psychology of Organizations, New York: Wiley, 1966.

Katz, Elihu, and Brenda Danet, Bureaucracy and the Public, New York: Basic Books, 1973.

Kelly, Marynell A., "Active versus Passive Ieadership Techniques with Development Groups", in Dissertation Abstracts International, Vol. 31, 5B-2990, November, 1970.

Kurtz, Russel H., "Administration of Social Agencies", in Social Work Yearbook, New York: National Association of Social Workers, 1957, p. $75-82$. 
Likert, Rensis, New Patterns of Mangement, New York: McGraw Hill Book Company, 196.

Litterer, Joseph, The Analysis of Organizations, New York: John Wiley and Sons, 1965.

Litwin, George $\mathrm{H}_{\bullet}$, and Robert A. Stringer Jr., Motivation and Organizational Climate, Boston: Harvard University, 1968.

Mailick, Sidney, Concepts and Issues in Administrative Behavior, Englewood Cliffs, New Jersey: Prentice Hal 1, 1962.

Moore, David G., "Human Relations in Organizations", in Concepts and Issues in Administrative Behavior, edited by Sidney Mailick, Englewood Cliffs, New Jersey: Prentice Hall, 1962.

Pigors, Paul and Charles Myers, Personnel Administration, New York: McGraw Hill Book Company, 1951.

Shore, Herbert H., "Resident Participation in Meal Planning", in Selected Articles on Nursing Homes, Washington D. C.: U. S. Department of $\mathrm{H}_{.} \mathrm{E} . \mathrm{W}_{\bullet}, 1960$.

Smigel M. D., Joseph 0., Erwin O. Smigel PhD., and Wilma H. Reiter, Nursing Home Administration, Springfield, Illinois, Charles C. Thomas Publishers, 1962.

Smith, Patricia Cain, Lorne M. Kendall, and Charles L. Hulin, The Measurement of Satisfaction on Work and Retirement: A Strategy for the Study of Attitudes, Chicago: Rand McNally and Company, 1969.

Sydnor, Gail Olmstead, and Patricia Mears Wold, Some Correlates of Morale Among Nursing Home Residents, Portland, Oregon: Portland State University, 1974 .

Tobin, Sheldon S., "Understanding the Elderly", in Nursing and Retirement Home Administration, edited by $\mathrm{H}$. Lee Jacobs and Woodrow $W$. Morris, Ames, Iowa: Iowa: Iowa State University Press, 1966.

Whitehead, Anthony, In the Service of Old Age: the Welfare of Psychogeriatric Patients, Baltimore, Maryland: Penguin Books, 1970. 
SEDICNGJdV 


\section{APFENDIX i}

\section{Biographical Responses and Fercentares}

Facility A

Length of Time with Agency

Education

Age

Facility $F$

Iength of Time with Agency

Equcation

Age

Facility C

Length of Time with Agency

Education

Àge

Facility D

Length of Time with Agency

Education

Age
$0-2 m o \cdot 2-6 m o \cdot 6-12 \mathrm{mo} \cdot 1-5 y r s .0 v e r 5 y r s$. $\begin{array}{cccc}5 & 4 & 11 & 2 \\ (22.7) & (18.2) & (50 .) & (9.1)\end{array}$

grade high vocat. bach. master other

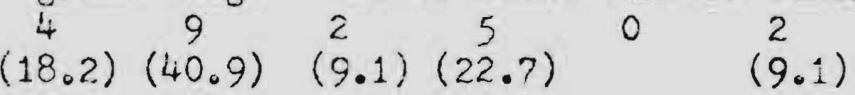
$\begin{array}{llllll}\text { teens } & 2 \mathrm{C}^{\prime} \mathrm{s} & 300^{\circ} \mathrm{s} & 4 \mathrm{C}^{\prime} \mathrm{s} & 50^{\circ} \mathrm{s} & 60^{\circ} \mathrm{s} \\ 2 & 7 & 5 & 2 & 6 & 0\end{array}$ $(9.1)(31.8)(22.7)(9.1)(27.3)$

0-2mo. 2-6mo. 6-i2mo.1-5yrs.over 5yrs. $\begin{array}{lllll}3 & 3 & 12 & 20 & 6 \\ (6.8) & (6.8) & (27.3) & (45.5) & (13.6)\end{array}$

grade high vocat. bach. master other $\begin{array}{cccccc}1 & 19 & 11 & 1 & 1 & 10 \\ (2.3) & (4.4 .2) & (25.6) & (2.3) & (2.3) & (23.3)\end{array}$ teens $20^{\circ} \mathrm{s} \quad 30^{\prime} \mathrm{s} \quad 40^{\circ} \mathrm{s} \quad 50^{\circ} \mathrm{s} \quad 60 \mathrm{~s}$

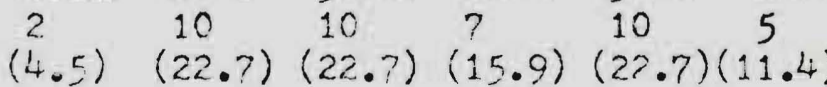

0-2mo. 2-6mo. 6-12mo.1-5yrs.over 5yrs. $\begin{array}{lllll}4 & 2 & 9 & 6 & 1\end{array}$ $(18.2) \quad(9.1)(40.9)(27.3) \quad(4.5)$

grade high vocat. bach. master other $\begin{array}{cccccc}4 & 8 & 4 & 2 & 0 & 4 \\ (18.2) & (36.4) & (18.2) & (9.1) & & (18.2)\end{array}$ $\begin{array}{llllll}\text { teens } & 20^{\prime} \mathrm{s} & 30^{\prime} \mathrm{s} & 40^{\prime} \mathrm{s} & 50^{\prime} \mathrm{s} & 60^{\circ} \mathrm{s} \\ 5 & 13 & 2 & 2 & 0 & 0\end{array}$ $(22.7) \quad(59.1)(9.1) \quad(9.1)$

$0-2 \mathrm{mo} .2-6 \mathrm{mo} \cdot 6-12 \mathrm{mo} \cdot 1-5 \mathrm{yrs} .0 \mathrm{ver} 5 \mathrm{yrs}$. 123 $(3).(27.3) \quad(69.7)$

grade high vocat. bach. master other $\begin{array}{llllll}4 & 15 & 2 & 2 & 1 & 9\end{array}$ $(12.1) \quad(45.5)(6.1) \quad(6.1) \quad(3) \quad.(27.3)$ $\begin{array}{llllll}\text { teens } & 20 \mathrm{~s} & 30 \mathrm{~s} & 40 \mathrm{~s} & 50^{\prime} \mathrm{s} & 60 \mathrm{~s} \\ 0 & 4 & 5 & 6 & 17 & 1\end{array}$ $(12.1)(15.2)(18.2)(51.5)(3$. 


\section{APFENDIX B}

\section{Cover Sheet for Schedule}

\section{Statement of Purpose}

The purpose of this questionaire is to collect data related to organizational structure, staff satisfaction, and client/patient satisfaction. The study is being conducted, with the permission of your administrator, to collect data for a master's practicum in social work.

Method

Some people here will be asked to complete this questionalre and some people will not be asked. For statistical reasons you have been randomly selected to f1ll out this questionaire. In order for the study to be successful it is very important that you take a few minutes right now to complete this questionaire. When you have completed the questionaire fold 1t, put 1t into the envelope supplied for this purpose, and seal the envelope. Return the envelope as designated.

\section{Confidentiality}

No one will know which questionalre is yours. Each individual's questionaire will be confidential and the end results will be shown in compiled scores of many individuals. Each service delivery agency used in this study will remain confidential. 
Please read each question carefully and then select the answer that best describes joav Circle that answer. Your answers are confidential.

1. Fy position in this agency is that of -.. aduinistrator(11) supervisor(12) professional staff(13) nonprofessional staff(14) client/patient(15)

2. length of association with this agency is -.

less than 2 monthe(21)

over 2 months to 6 months(22)

over 6 months to 1 year(23)

over 1 year to 5 years (24)

over 5 jears (25)

3. The highest level of education I completed is -.. (31)

grade $\operatorname{school}(32)$

GED or high school(33)

vocational school (34)

bechelors degree,college(35)

master degree, college(36)

other

4. I am in ms $\ldots$

late teens (41)

sixt1es(46)

twent1es (42)

seventies (47)

thirties (43)

elghties (48)

fort1es (44)

nint1es (49)

fifties(45)

hundreds 
In this section please select the answer that best describes how you feel and circle that answer. Please answer all the questions.

SA-STRONGLY AGREE MA-MODERATELY AGREE N-NEUTRAL

MD-MODERATELY DISAGREE SD-STRONGLY DISAGREE

5. Taking all things together I am well satisfied with the way things are here。 $\quad S A(51) \quad M A(52) \quad N(53) \quad M D(54) \quad S D(55)$

6. All things considered I feel well satisfied about how I am treated here.

$$
\mathrm{SA}(61) \quad \mathrm{MA}(62) \quad \mathrm{N}(63) \quad \mathrm{MD}(64) \quad \mathrm{SD}(65)
$$

7. I feel I am encouraged to make my own decisions here.

$$
\mathrm{SA}(71) \quad \mathrm{MA}(72) \quad \mathrm{N}(73) \quad \mathrm{MD}(74) \quad \mathrm{SD}(75)
$$

8. I feel I am encouraged to give my opinion before decisions concerning me are made by someone else. $\quad S A(81) \quad M A(82) \quad N(83) \quad M D(84) \quad S D(85)$

9. I feel I am encouraged to have an equal voice in making decisions concerning me. $\quad S A(91) \quad M A(92) \quad N(93) \quad M D(94) \quad S D(95)$

10. I feel I am not encouraged to give my opinion on decisions concerning me. $\quad S A(101) \mathrm{MA}(102) \mathrm{N}(103) \mathrm{MD}(104) \operatorname{SD}(105)$

11. People are usually capable of making good suggestions regarding decisions that affect them. $S A(111)$ MA(112) N(113) MD(114) SD(115) 
12. It's hard to get people to take responsibility.

$$
\text { SA(121) MA(122) N(123) MD(124) SD(125) }
$$

13. Most people are capable of directing and controlling what they do here.

$$
\mathrm{SA}(131) \mathrm{MA}(132) \mathrm{N}(133) \mathrm{MD}(134) \mathrm{SD}(135)
$$

14. A very friendly atmosphere prevalls among the people here.

SA(141) MA(142) N(143) MD(144) SD(145)

15. People get along with each other very well here.

$$
\mathrm{SA}(151) \mathrm{MA}(152) \mathrm{N}(153) \mathrm{MD}(154) \mathrm{SD}(155)
$$

16. The philosophy of our management emphasizes such traits as kindness, consideration, fairness, feelings, and service.

$$
\mathrm{SA}(161) \mathrm{MA}(162) \mathrm{N}(163) \mathrm{MD}(164) \mathrm{SD}(165)
$$

17. I feel I am treated as a person with feelings here.

$$
S A(171) \quad M A(172) N(173) M D(174) S D(175)
$$


APFENDIX D

Home A Responses and Percentages

$n=22$

\begin{tabular}{|c|c|c|c|c|c|}
\hline Variable & SA & $N / 4$ & $\mathrm{MD}$ & SD & tot \\
\hline General Satisfaction Here & $(1+5)$ & $(63.6)(31.8)$ & 0 & 0 & 22 \\
\hline Satisfaction Way Treated Fere & $(22 \cdot 7)$ & $\begin{array}{l}13 \\
(59.1)(18.2)\end{array}$ & 0 & 0 & 22 \\
\hline Ferceived Laissez-faire Leadershi & $(31.8)$ & $(27.3)(40.9)$ & 0 & 0 & 22 \\
\hline Ferceived Democratic Leadership & $\begin{array}{c}8 \\
(36.4)\end{array}$ & $\begin{array}{c}3 \\
(13.6)(45.5)\end{array}$ & $(4 \cdot 5)$ & 0 & 22 \\
\hline Ferceived Leadership Allows Input & $(25)$. & $(20).\left(\begin{array}{c}9 \\
5 .\end{array}\right)$ & $(10)$. & 0 & 20 \\
\hline Ferceived Autocratic Leadership & $\begin{array}{l}2 \\
(9.1)\end{array}$ & $\begin{array}{l}11 \\
(50 .)\end{array}$ & $\begin{array}{c}3 \\
(13.6)\end{array}$ & $(27 \cdot 3)$ & 22 \\
\hline People Capabie of Making Decisions & $(9.5)$ & $\begin{array}{l}12 \\
(57.1)(33 \cdot 3)\end{array}$ & 0 & 0 & 21 \\
\hline Peocle Don't Want Fesponsibility & $(18.2)$ & $(5,13)(13.6)$ & $\begin{array}{l}2 \\
(9.1)\end{array}$ & 0 & 22 \\
\hline People Capable or Decisions Here & $\stackrel{2}{(9.1)}$ & $(36.4)(110.9)$ & $\begin{array}{l}3 \\
(13 \cdot 6)\end{array}$ & 0 & 22 \\
\hline Friendly Atmosphere Here & $\begin{array}{l}1 \\
(4 \cdot 5)\end{array}$ & $\begin{array}{cc}11 & 10 \\
(50 .) & (45.5)\end{array}$ & 0 & c & 22 \\
\hline Feople Get Along well Here & $\begin{array}{l}1 \\
(4.5)\end{array}$ & $\begin{array}{cc}9 & 10 \\
(40.9)(45.5)\end{array}$ & $\left(\frac{1}{4 \cdot 5)}\right.$ & $\left(\begin{array}{l}1 \\
(4 \cdot 5)\end{array}\right.$ & 22 \\
\hline $\begin{array}{l}\text { Philosophy of Management } \\
\text { Criented to Feocle }\end{array}$ & $(31.8)$ & $\begin{array}{c}8 \\
(54.5)(27 \\
(3)\end{array}$ & 0 & 0 & 22 \\
\hline Feel Treated as a Ferson & $\left(\begin{array}{l}4 \\
(8.2) \\
\end{array}\right.$ & $\begin{array}{cc}12 & 6 \\
(54 \cdot 5)(27 \cdot 3)\end{array}$ & 0 & 0 & 22 \\
\hline
\end{tabular}

Coded $\mathrm{SD}=$ Strongly Agree, $\mathrm{MD}=$ Moderately Agree, $N=$ Neutral, MD=Moderately Disagree, $S D=S t r o n g l y$ Disagree 
Home B Responses and Fercentages

\begin{tabular}{|c|c|c|c|c|c|c|}
\hline Variable & SA & $\mathrm{m}$ & $\mathrm{N}$ & ND & SD & Tota \\
\hline General Satisfaction Here & $\left(\begin{array}{ll}19 \\
(43.2)\end{array}\right.$ & $\begin{array}{l}21 \\
(47 \cdot 7)\end{array}$ & $\begin{array}{l}1 \\
(2.3)\end{array}$ & $(6.8)$ & 0 & 44 \\
\hline Satisfaction Way Treated Here & $\begin{array}{c}33 \\
(75 .)\end{array}$ & $\begin{array}{l}10 \\
(22.7)\end{array}$ & $\frac{1}{(2.3)}$ & 0 & 0 & 4.4 \\
\hline Ferceived Laissez-faire Leadership & $\begin{array}{l}\text { p } 22 \\
(50 .)\end{array}$ & $(31.8)($ & $(11.4)$ & $\stackrel{1}{(2.3)}$ & $\stackrel{2}{(45)}$ & 4 \\
\hline Ferceived Democratic Leadership & $\begin{array}{l}26 \\
(60.5)\end{array}$ & $\begin{array}{l}10 \\
(23 \cdot 3)\end{array}$ & $\left(\frac{1}{2 \cdot 3)}\right)$ & $\begin{array}{l}4 \\
(9.3)\end{array}$ & $\stackrel{2}{(4 \cdot 7)}$ & 43 \\
\hline Perceived Leadership Állows Input & $\begin{array}{l}27 \\
(62.8)\end{array}$ & $(20.9)$ & $\frac{1}{(2 \cdot 3)}$ & $(11.6)$ & $\dot{i}(2.3)$ & 43 \\
\hline Perceived Autocratic Leadership & $\left(\frac{3}{7}\right)$ & $\begin{array}{l}4 \\
(9.3)(\end{array}$ & $(11.6)$ & $(11.6)$ & $\begin{array}{l}26 \\
(60.5)\end{array}$ & 43 \\
\hline Feople Capable of Making Decisions & s 8 & $\begin{array}{l}27 \\
(62.8)(\end{array}$ & $(11 \cdot 6)$ & $(3)$ & 0 & 1 \\
\hline Feople Don't Want Responsibility & $\begin{array}{l}10 \\
(22.7)\end{array}$ & $\begin{array}{l}22 \\
(50 .)\end{array}$ & $\stackrel{3}{(6.8)}$ & $(11.4)$ & $\left(\begin{array}{l}4 \\
9.1\end{array}\right)$ & 44 \\
\hline Feople Capable of Decisions Here & $(20.9)$ & 24 & $\stackrel{2}{(4.7)}$ & $\left(\begin{array}{l}? \\
(16 \cdot 3)\end{array}\right.$ & $123)$ & 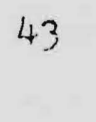 \\
\hline Friendly Atmosphere Here & $\begin{array}{l}21 \\
(47 \cdot 7)\end{array}$ & $\begin{array}{l}19 \\
(43.2)\end{array}$ & $\begin{array}{l}4 \\
(9.1)\end{array}$ & 0 & 0 & 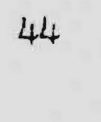 \\
\hline Feople Get Along Vell Here & $\begin{array}{l}14 \\
(32.6)\end{array}$ & $\begin{array}{l}22 \\
(51.2)(\end{array}$ & $\begin{array}{c}6 \\
(14 .)\end{array}$ & $\frac{1}{(2 \cdot 3)}$ & 0 & 43 \\
\hline $\begin{array}{l}\text { Philosophy of Management } \\
\text { Oriented to Feople }\end{array}$ & $\begin{array}{l}38 \\
(86.4)\end{array}$ & $(11.4)$ & $\stackrel{1}{(2 \cdot 3)}$ & 0 & 0 & 44 \\
\hline Feel Treated as a Ferson & $\begin{array}{l}35 \\
(79.5)\end{array}$ & $\begin{array}{l}7 \\
(15.9) \\
\end{array}$ & $\begin{array}{l}1 \\
(2.3) \\
\end{array}$ & $\begin{array}{l}1 \\
(2.3) \\
\end{array}$ & 0 & 44 \\
\hline
\end{tabular}

Coded $S D=$ Strongly Agree, $N_{A}=$ Moderately Agree, $N=$ Neutral, Mn=Moderately Disagree, $S D=$ Strongly Disagree 
Home C Responses and Percentages

$n=22$

\begin{tabular}{|c|c|c|c|c|c|}
\hline Vor:able & $S A$ & Wi & $\because D$ & $3 D$ & Total \\
\hline General Satiofaction Fere & $\begin{array}{c}6 \\
(27 \cdot 3)\end{array}$ & $(50).(13.6)$ & $\left(\begin{array}{l}1 \\
4.5\end{array}\right)$ & $(4 \cdot 5)$ & 22 \\
\hline Satisfaction iay Treated Yere & $\begin{array}{l}10 \\
(45 \cdot 5)\end{array}$ & $\begin{array}{cc}8 & 1 \\
(36.4) & (4.5)\end{array}$ & $(\hat{a}, 1)$ & $(4.5)$ & 22 \\
\hline Ferceived laissez-faire leadership & 99 & $\begin{array}{cc}8 & 2 \\
(36.4) & (0.1)\end{array}$ & $\begin{array}{l}2 \\
(9 \cdot 1)\end{array}$ & $\left(\begin{array}{l}1 \\
(i \cdot 5)\end{array}\right.$ & 22 \\
\hline Ferceived Derrocratic Leadership & $\begin{array}{l}8 \\
(36.4)\end{array}$ & $(40.9)(9.1)$ & $\begin{array}{l}2 \\
(9.1)\end{array}$ & $\left(\frac{1}{4 \cdot 5)}\right)$ & 22 \\
\hline Perceived leadership Allows Inout & $(36.4)$ & $\begin{array}{cc}8 & 1 \\
(36.4) & (4.5)\end{array}$ & $(18.2)$ & $(4.5)$ & 22 \\
\hline Ferceived Autocratic Leadershin & $(4 \cdot 5)$ & $\begin{array}{l}2 \\
(9.1)(18.2)\end{array}$ & $(31.8)$ & $\begin{array}{c}8 \\
(36.4)\end{array}$ & 22 \\
\hline Foople Capable of Vaking Decisionis & $=\frac{6}{(27 \cdot 3)}$ & $\left(\begin{array}{ll}11 & 2 \\
(50 .) \quad(9.1)\end{array}\right.$ & $(13.6)$ & 0 & 22 \\
\hline Eeople Don't rant Responsibility & $\left(\frac{1}{4 \cdot 5)}\right.$ & $\begin{array}{cc}10 & 6 \\
(45 \cdot 5)(27 \cdot 3)\end{array}$ & $(18.2)$ & $\left(\begin{array}{l}1 \\
(4 \cdot 5)\end{array}\right.$ & 22 \\
\hline Feople Capable of Decisions Here & $(22 \cdot 7)$ & $\left(\begin{array}{l}11 \\
(50 .)(18.2)\end{array}\right.$ & $\stackrel{2}{(9.1)}$ & 0 & 22 \\
\hline Friendly itmosphere Here & $(31.8)$ & $\begin{array}{cc}12 & 2 \\
(54.5) & (9.1)\end{array}$ & 0 & $(4 \cdot 5)$ & 22 \\
\hline Feople Get filong vell Here & $\begin{array}{c}8 \\
(36.4)\end{array}$ & $\begin{array}{cc}10 & 1 \\
(45.5) & (4.5)\end{array}$ & $\begin{array}{l}2 \\
(9.1)\end{array}$ & $\left(\begin{array}{l}1 \\
(4 \cdot 5)\end{array}\right.$ & 22 \\
\hline $\begin{array}{l}\text { Philosophy of Management } \\
\text { Criented to People }\end{array}$ & $\begin{array}{l}10 \\
(45.5)\end{array}$ & $\left(\begin{array}{c}6 \\
(27.3)(19.2)\end{array}\right.$ & $\begin{array}{l}2 \\
(9.1)\end{array}$ & 0 & 22 \\
\hline Feel Treated as a Ferson & $\begin{array}{c}9 \\
(40.9)\end{array}$ & $\begin{array}{cc}8 & 2 \\
(36.4) & (9.1)\end{array}$ & $(13.6)$ & 0 & 22 \\
\hline
\end{tabular}

Coded SD=Strongly Agree, MA=Noderately Agree, $N=$ Neutral, MD=Moderately Disarree, SD=Strongly Disagree 


\section{A.P ENDIX E}

Significant Relationships with Non-demccratic Leadership stvles

Variable

Chi Suvare Spearman

Facility A

Laissez-faire Leadership/Nanagement Fhilosophy 14.91922* . 7321 *

General Satisfaction/Input Leadership ?.21209*

Satisfaction Treated/Autocatic Leadership $18.43590 * \quad-.5817 *$

Autocratic Leadership/Nanagement Frilosorhy $\quad 25.38095 *-.4278 *$

Autocratic Leadership/Treated as Person $16.55556 * \quad-.4325 *$

Facility E

General Satisfaction/Laissez-faire Leadership

Satisfaction Treated/Iaissez-faire Leadership

Laissez-faire Leadershio/Treated as Ferson

$33.5259 *$

$30.11481 * \quad .451 \% *$

General Satisfaction/Incut Leadersinip

Satisfactio: Treated/Input Leadership

Inrut Ieadership/Nanapement Thilosorhy

Input Leadership/Treated as Ferson

$10.14041 * .4970 *$

Satisfaction. Treated/Autocratic Leadership

$25.36520 * \quad .2943 *$

$52.890 * \quad .4925 *$

$57.07508^{*}$

$52.67053^{*} .5864 *$

Autocratic Leadership/Varagement Thilosoniny

$28.24046 *-.4878 *$

Autocratic Leadership/Treated as Ferson.

$16.63322 *-.2747 *$

$45.50956 *-.5449 *$

Facility $\mathrm{C}$

\begin{tabular}{|c|c|c|}
\hline $\begin{array}{l}\text { General Satisfaction/Laissez-faire leadership } \\
\text { Sutisfaction Treated/Laissez-faire Leadership } \\
\text { Laissez-faire Leadership/Treated as Ferson }\end{array}$ & $\begin{array}{l}31.8750 * \\
61.04375 * \\
31.52739 *\end{array}$ & $\begin{array}{l}.4742^{*} \\
.6971 * \\
.6969 *\end{array}$ \\
\hline $\begin{array}{l}\text { General Jatisfacticn/Incut Leaciership } \\
\text { Satisfaction Treated/Input Leadership }\end{array}$ & $\begin{array}{l}41.50 * \\
33.8250 *\end{array}$ & $\begin{array}{l}-? 72,4 * \\
-6042 *\end{array}$ \\
\hline Autocratic I & $14 *$ & \\
\hline
\end{tabular}

Facility D

Satisfaction Treated/Laissez-faire Leadership 45.01436* .4185*

Laissez-faire Leadership/Treated as Fersor. 29.03401* .6201*

Input Leadership/Management Philosophy $\quad 27.42792 * \quad .3044 *$

Input Leadership/Treated as Ferson $\quad 28.33651 * \quad .6210^{*}$

* These figures applied to a stinderdized table at certain degrees of freedom are significant at a .05 Ievel. 